\title{
ANALYSIS OF APPLICATION OF ACCOUNTING INFORMATION SYSTEM IN PROCESSING SALES TRANSACTION AT PT. DAIHATSU ASTRA MOTOR SISINGAMANGARAJA
}

\author{
Budiman Rosyadi Nasution \\ Universitas Alwashliyah Medan \\ E-mail: mastasembiring@umsu.ac.id
}

\begin{abstract}
This study aims to examine the sales accounting information system implemented by PT Daihatsu Astra Motor Sisingamangaraja. Then it can be identified whether the information system has been implemented according to the right internal control structure or not and to determine the company's development through financial ratios that are limited to the sales department. This type of research is a case study, which contains exposure or relevant data from the results of research on the object. Qualitative methods are used in flowchart analysis and quantitative methods are used to calculate financial ratios that are limited to sales. Primary data is data that comes from the original source and is collected specifically for the purposes of the research being conducted. Secondary data is data produced by companies such as financial statements and accounting records. Data collection methods are interviews and direct observation. The results of this study are overall PT Daihatsu Astra Motor Sisingamangaraja has carried out car sales activities, spare parts / spare parts and service services with an accounting information system in accordance with the components of the internal control structure model. The majority of transactions that occurred at PT Daihatsu Astra Motor Sisingamangaraja actually decreased, this was due to the author's limitations in obtaining related financial statement information. Thus, it can be concluded that the accounting information system applied by the company is mostly appropriate and effective because it is appropriate so that it can support internal sales control.
\end{abstract}

Keywords: Accounting Information System, Sales, Effectiveness of Internal Control

\section{INTRODUCTION}

Technological developments in the manufacture of sophisticated applications for accounting information systems can help and facilitate the preparation of financial information systems for companies in Indonesia, both small, medium and large companies. The company's accounting information system is used as a technology to compile and produce quality information. In order to support sales activities, a manager is very interested in information related to sales, to present information about sales so that it can be used to make further decisions.

The accounting information system is the main formal system in most companies. A formal information system is a system that describes in writing the responsibilities of making information. Financial events that occur are communicated through the accounting information system to interested parties in the form of activity reports. In profit-oriented companies, sales are the main activity to achieve the main goal. In order to support sales activities, a manager is very interested in information related to sales, to present information about sales so that it can be used to make further decisions. The purpose of the accounting system is to improve internal control and to improve better information, in addition to reducing administrative costs or administrative costs, and to determine the implementation of the production process so that it is easier to carry out planning and prevent unhealthy company operations. The accounting system is also a company control tool in saving company assets.

This internal control system is run by the board of commissioners, management and other board personnel designed to provide reasonable assurance regarding the achievement of objectives, namely, reliability of financial reporting, compliance with applicable laws and regulations, 
Analysis of Application of Accounting Information System in Processing Sales Transaction At PT. Daihatsu Astra Motor Sisingamangaraja

DOI: $10.54443 /$ morfai.v1i2.117

effectiveness and efficiency of operations. Therefore it is necessary to evaluate the internal control system on sales to maintain the viability of the company and the achievement of company goals.

The process of developing procedures and systems is usually carried out together with related procedures and is not a separate procedure. Control over sales distribution systems and procedures aims to control the process so that the established systems and procedures can run in accordance with the predetermined plans. On the other hand, through the proper application of sales accounting information systems, the company can avoid deviations from sales activities that occur, both credit and cash sales.

\section{IMPLEMENTATION METHOD}

This type of research is a case study, which contains exposure or relevant data from the results of research on the object. In this case, the research seeks to examine and provide solutions to the problems faced by the object company, which are related to sales systems and procedures. The data used is qualitative, namely in the form of sentences that describe the general state of a company. The data used are primary data and secondary data. Primary data is data that comes from the original source and is collected specifically for the purposes of the research being carried out. Secondary data is data produced by companies such as financial statements and accounting records. Researchers conducted directly to PT Daihatsu Astra Motor Sisingamangaraja.

\section{RESULTS AND DISCUSSION}

This study researchers have observed the functions related to the sales accounting information system, namely the existence of a network of procedures that form a system of car sales in cash and credit, spare parts sales and services.

\subsection{Control Environment}

Intergrity and ethical management values in each division every morning, they do regular meetings every day for approximately 30 minutes. And on Monday, a meeting was held for all divisions, at this meeting the management provided the latest information related to information from PT Daihatsu Astra Motor and there was a sharing between staff and management to increase the value of integrity and management ethics that affect the performance of PT Daihatsu Astra Motor staff. . Meetings for each division are usually held every day except Monday. Organizational structure and duties of authority as a business entity, PT Daihatsu Astra Motor has an organizational structure in accordance with the objectives of the business sector. The organizational structure of the company can be identified by describing the organizational chart so that a clear picture of the duties, authorities, and responsibilities of each position in the organization is obtained. Parameters for carrying out governance oversight responsibilities PT Daihatsu Astra Motor every transaction will only occur on the basis of the authority of the official who has the authority to approve the occurrence of the transaction, therefore in the organization a system is made that regulates the distribution of authority to the authority for the implementation of each transaction. Based on observations made by the author, there is an annual tax report to the Directorate General of Taxes. This proves that PT Daihatsu Astra Motor has also received an inspection by a government agency. Develop, and retain competent individuals PT Daihatsu Astra Motor has a policy in the form of sales targets and car sales turnover. It's just that for sales turnover the management refuses to provide an exact figure of turnover to achieve this target. In practice, PT Daihatsu Astra Motor manages human resources well. The methods that are carried out include selection of prospective employees based on the requirements demanded in accordance with the required fields. Performance measurement, incentives and rewards to encourage performance accountability the management has a complete record of all employee work from the Otobitz System and in every corner of the workspace there is CCTV to assess employee performance. 


\subsection{Risk Assessment}

The organization establishes objectives with sufficient clarity to allow identification and assessment of risks associated with the objectives. Changes in the operational environment impose new pressures or changes in pressure on the company, of course, it is a risk to staff performance and automatically affects sales targets. In carrying out the recruitment of new employees, especially in the sales department, employee selection is usually carried out starting from IQ tests, interviews and training will be given first. It also aims to provide comfort and will have an effect on staff performance. This organization considers the potential for fraud in assessing risks to the achievement of objectives. Implementation of new technology into the production process or information that has an impact on transaction processing, can be prevented by maximizing staff understanding of the implementation of new technology so that the impact of errors on transaction processing can be minimized. Organizational restructuring is a common thing in a company. This may pose a risk to transaction processing. But the management provides full awareness of the manager and staff. The organization identifies and assesses changes that could significantly affect the system of internal control. For some cases, there are difficulties with proper internal control if there is too significant and rapid growth, but PT Daihatsu Astra Motor has anticipated this by using a large number of staff to minimize the risk of internal control difficulties.

\subsection{Control Activities of These Policies and Procedures among other:}

a. The sales budget has been used, which functions as a control for the sales department, so that the sales department has a target and then it will be matched with the actual sales results.

b. Physical control is carried out routinely by counting goods in the warehouse.

c. For the management of sales information, there is general control that handles the company's database by IT and control has been carried out via a computer using the application used, namely Otoblitz.

\section{Discussion}

Information and Communication Methods and records contained in PT. Daihatsu Astra Motor, is the result of the process and management of sales data, along with the data used by PT. Daihatsu Astra Motor

a. The use of forms, records, procedures and sales reports, which have been applied are adequate and presented validly, so as to provide reliable information.

b. Have recorded all valid financial transactions, this is evident from the checks between the cashier and financial staff on a regular basis.

c. Good communication between the company's leadership and staff, can be seen from the compliance with policies in the sales sector, as outlined by the leadership.

d. Various transactions are recorded accurately by the cashier and reported to the financial staff, then periodic inspections and journals are made by the accounting department. For example, daily, monthly, quarterly and annual reports.

\section{Supervision Continuous Monitoring Of Sales Activities}

Supervision continuous monitoring of sales activities is carried out in the form of continuous supervision of company activities by studying internal reports made in connection with internal sales control. Monitoring can be done directly through Otobitz by the managers concerned, in addition to checking physical documents that have been stored.

\section{CONCLUSION}

This study based on the analysis carried out, conclusions are drawn, among others: 
Analysis of Application of Accounting Information System in Processing Sales Transaction At PT. Daihatsu Astra Motor Sisingamangaraja

DOI: $10.54443 /$ morfai.v1i2.117

1. He sales accounting information system applied to the company is carried out in a computerized manner.

2. Sales made by PT. There are two types of Daihatsu Astra Motor, namely: Cash Sales \& Credit Sales.

3. The accounting information system implemented by the company is mostly appropriate and effective because it is appropriate so that it can support internal sales control.

4. The company has also conducted or implemented education and training programs, especially in the field of sales in an effort to improve the ability of employees according to their work needs with the hope that the company has competent and honest employees in carrying out activities in the company.

\section{REFERENCES}

Bodnar, George H. William S. Hoopwood, 2000, Accounting Information Systems, Translated by Amir Abadi jusuf and R. M Tambunan, Sixth Edition, Book one, Salemba Empat, Jakarta.

Baridwan, Zaki Dr. M.Sc., Accountants. 1993. Accounting information system. BPFE-Yogyakarta : Yogyakarta.

Committee of Sponsoring Organization of the Treadway Commission (COSO). 2013. Internal Control Integrated Framework. New York: AIGPA's Publication Division.

Cushing, Barry E. et al. 1989. Accounting Information Systems and Company Organization. Erlangga Publisher : Jakarta.

Herdianti, Anita. 2011. Application of Credit Sales Accounting Information System at PT Karya Lancar Mandiri Dinamika Kendari. Halooleo University. http://www.scribd.com/doc/110854019/PenerapanSistem-Accountansi-Penjualan-Kredit accessed on 03 March 2014. http://hondasolobaru.com/blog/ accessed on 22 August 2014.

James A. Hall. 2009. Accounting Information Systems. Salemba Four: Jakarta. Krismiaji. 2002. Accounting Information Systems. UPP AMP YKPN: Yogyakarta.

Manurung, Zulkarnain. 2010. Analysis of Sales Accounting Information Systems PT Mutifa - Medan Pharmaceutical Industry. University of North Sumatra http://repository.usu.ac.id/handle/123456789/19771 accessed on 03 March 2014.

Mulyadi, 2002, Auditing, 6th Edition, First printing, Books one and two, Salemba Empat, Jakarta.

Rommey, Marshal B. and Paul John Steinbart, 2004, Accounting Information Systems, Book 1, Edition 9, Salemba Empat, Jakarta.

Rommey, Marshal B. and Paul John Steinbart, 2004, Accounting Information Systems, , Book 2, Edition 9, Salemba Empat, Jakarta. 